\title{
The Contemporary Election Campaign in Romania: Approaching the Electorate through Online and Offline Communication Channels. Case study: The European Parliament Elections 2019
}

\author{
Lecturer Veronica CÂMPIAN, PhD \\ Faculty of Communication, Public Relations and Advertising \\ Babeș-Bolyai University, Cluj-Napoca, Romania \\ E-mail: campean@fspac.ro
}

\section{Brîndușa Maria CERGĂ}

Faculty of Communication, Public Relations and Advertising

Babeș-Bolyai University, Cluj-Napoca, Romania

E-mail: brindusa.maria@yahoo.com

\begin{abstract}
The article "The Contemporary Election Campaign in Romania: Approaching the Electorate through Online and Offline Communication Channels; Case study: The European Parliament Elections 2019" deals with the elections for the European Parliament in Romania and sets out to examine how two political parties, the Social Democratic Party (PSD) and the coalition Union Save Romania-PLUS (USR-PLUS), have approached the electorate through online and offline communication channels. The text is based on the following research question, namely how do the political parties operate on the social platform Facebook in the month before the elections? If we assume, that the social platform Facebook is to be seen as a feedback carrier, then we want to examine how and to what extent the interested citizens show a feedback reaction to the posted content. This article is also based on the following hypothesis: The newly formed coalition USR-PLUS deals with a greater variety of topics through its online and offline communication channels than the already well-known and established PSD.
\end{abstract}

Keywords: Social media; Facebook; Newspaper; Online and offline communication channels; Political party; Election campaign. 


\section{Introduction}

This article deals with the issue of election campaigns in Romania and aims to examine how the political actors and their parties are approaching the electorate. There are traditional, classic, but also modern and new communication channels. This paper examines a traditional election campaign tool, namely the party newspapers of two parties, the Social Democratic Party (PSD) and the Union Save Romania-Plus (USR-PLUS). It also deals with social networks, namely the Facebook accounts of these two political parties. Our focus is to determine how the relationship with the electorate is established, how and by which topics the public agenda is shaped and finally how the citizens are mobilized and challenged for content participation.

The present paper revolves around two political parties, the PSD and the USRPLUS, which took part in the 2019 European elections and which are strictly separated ideologically and politically from each other. PSD is an established political left-wing party with a long history in the Romanian political system, while USRPLUS is a newly formed political alliance representing the right-wing ideology. It is precisely these differences that are considered a key factor in any further analysis of the issues that shape the electorate's agenda.

During election times particularly, the parties and their leaders strive to ensure that their messages reach the population and that potential voters reflect on the issues they propose. The thematic function attributed to the media, also known as the Agenda Setting approach, describes the fact that the media does not influence people's thinking, but what they think about. (McCombs \& Shaw, 1972; Reese, 1991; Rössler, 1997; 2006; McCombs, 2004; McCombs \& Reynolds, 2009). Agenda Building, an extension of Agenda Setting (Maurer 2016: 419), describes the communication process through which political actors place their themes in the media coverage (Melischek/Rußmann/Seethaler). This kind of placement of their most important themes happens mainly in election campaigns, when political actors try to approach the voter through online and offline channels and strategic political communication and to confront him/her with these topics.

\section{Election communication in real and virtual space: evolution, functions and strategies}

\subsection{The typology of election campaigns}

The election campaign is a political battle between parties and/or political actors to obtain popular support and acceptance for their programs and projects. Every election campaign uses a variety of strategies, but above all, needs a wellthought communication between the political actors and the citizens with the right to vote. Politicians use the classic and modern media to build their programs, proj- 
ects and objectives public. The classic channels of communication continue to be a means for mobilizing the electorate, but in addition to attracting the attention of the electorate and shaping the public agenda, public events are organized and party newspapers and leaflets are also distributed.

Beyond these traditional media, social media and platforms such as Facebook are gaining an increasing role in the dissemination of political issues. Online communication on social networks is used as a tool in the election campaign to reach potential voters, to mobilize them to participate in political speeches, and, if possible, to get their vote.

Pippa Norris (2000, 137-138) identifies the changes that have taken place in the field of election communication during the last decades and describes three stages of evolution from the premodern to the modern and finally to the postmodern campaigns. This transition from one stage to the next brings changes in the area dealing with the organization of election campaigns, media use, feedback, costs and electorate. The pre-modern election campaign, which encompasses the period between the $19^{\text {th }}$ century and the 1950 s, is characterized in particular by local campaign activities. The campaigns were decentralized and communication with the voter was mainly direct, e.g. through the partisan local press. The electorate was generally characterized by a clear party affiliation, on which political actors and their parties could rely.

The modern election campaign (early 1960s-late 1980s) revolves around the broadcasting of television and evening news, which played a major role in election communication. The election campaign was, back then, nationally structured and its implementation was more long-term and professional (Norris, 2000, 137-138).

The postmodern election campaign is ongoing (1990s-today) and is particularly marked by the professionalization of the approach. Experts in the field of political communication are becoming increasingly important. But these professionals also bring higher costs. The parties face a "fluid electorate" (Rottbeck, 2013, 55), which does not always remain loyal to the same party and often seeks an election alternative. The media addresses no longer the entire audience, but it addresses different target groups in a differentiated way, which has as a consequence a selective use of the offers.

\subsection{The transition from the classic to the online election campaign}

Gibson and Ward $(2000,305)$ describe four functions of the political online communication that parties or political actors can perform in the election campaign: information, networking, mobilization (campaigning) and promoting participation. These functions serve the main purpose of an election campaign, namely to recruit potential voters. 
According to Gibson and Ward, Hinz $(2017,171)$ explains the importance of these functions. "Informing citizens has a value for the legitimacy of politics" and the main role of the information function is to "create a political public" $(2017,171)$. The special importance of this function is also underlined by Panagopoulos. "For many campaigns, a key benefit of new media and the Web is the massive amount of information they can provide to potential voters at the click of a button." (Panagopoulos, 2009, 12). The author also underlies, that never before have so many people been reached so quickly.

By sending political content, but also through networking, "political thinking can be influenced" (Hinz, 2016, 67) and the interest of those entitled to vote in the political process can also intensify. Hinz goes on to say that "connecting with citizens, mobilizing them and promoting their participation leads to the involvement of citizens in the political process." $(2017,171)$.

The possibility of participation, that the Internet induces, is a strategic advantage of online campaigns, because it enables the integration of the user into communication (Emmer, 2019: 382), but also his political participation. The dimensions of political participation and engagement were discussed by Voss $(2014,13)$, according to Jensen et al. $(2012,3)$. Their approach focuses on three dimensions: political participation, political information consumption and political attitudes. The political participation lies in the offline representative (e.g. voting, contacting) and extrarepresentative (e.g. protest, consumerism). In the online, the political participation is either vertical and unidirectional (e.g. online petitions, donation), or horizontal and interactive (e.g. blogging, posting political comments, joining political groups in social networks) (Voss, 2014, 13). This horizontal and interactive dimension is further described in the online analysis focused on Facebook. In this context, the comments posted by users are considered.

Based on the existing studies about the activity and presence of political parties on the Web, Gibson and Ward $(2000,304)$ summarize these findings and underline the following five differences between new and traditional media. The world wide web is characterized by the following: "(a) volume: larger quantities of information can be sent, (b) speed: the compression of data [...] decreases the amount of time it takes to send a message, (c) format: the style of the message sent has changed and [...] election communication allows information to be sent in audio, video and the text form, (d) direction: the possibilities for two-way and truly interactive or synchronous communication are greatly expanded on the Web, (e) individual control: given the opening up of control over the direction in the sending and receiving of messages" (Gibson and Ward, 2000, 34). So, "the web-based communication has the potential to be more immediate, dynamic, in-depth, interactive [...] than is possible in conventional media". (Gibson and Ward, 2000, 305). This idea is also reiterated by Denton, Trent and Friedenberg (2019), the authors highlighting the role and the impact of the new technology. "Without question, the wave of new com- 
munication technology has impacted the creation, collection and dissemination of information. In addition, the new media enhances citizen issue understanding and political engagement." (Denton, Trent, Friedenberg, 2019, 336).

In conclusion, we understand that "the traditional media promote largely oneway, downward political communication from elite to the masses. [...] The new media allow for multidirectional flows of information that open up the possibilities for more upward and interactive transmission." (Gibson \& Ward, 2000, 316).

\section{Methodological design}

The present study is based on a main research question, supported by secondary questions. In addition, the research also focuses on a hypothesis that revolves around the thematic content of the two aforementioned newspapers.

The main research question aims to answer how political parties operate on the social platform Facebook in the month before the elections? If we assume that the social platform Facebook is to be seen as a feedback carrier, then we want to examine how and to what extent the interested citizens provide feedback to the content posted.

Therefore, some secondary research questions have been phrased: What is shaping the audience agenda of the political parties PSD and USR Plus during the European Parliament Elections electoral campaign? What topics addressed were considered important by the electorate? How has the public seen the electoral message and how did it react to posts?

This paper is also based on the following hypothesis: The newly formed coalition USR-PLUS deals with a greater variety of topics through its online and offline communication channels than the already well-known and established PSD. These topics are listed and if thematic overlaps are identified, the aim is to find out from what perspective the two parties are dealing with this issue.

The Facebook pages of the two parties, as well as the two corresponding distributed newspapers count as the corpus of the analysis. USR-PLUS has offered their newspaper to pedestrians. PSD, on the other hand, has placed it in the letterbox of retired people together with their retirement documents.

\section{The Facebook Analysis}

The online analysis focuses on the Facebook content and it is based on the posts that the political parties, USR-PLUS and PSD, published during the month before the European Parliament Elections. The timeframe ranges between the $26^{\text {th }}$ of April and the $25^{\text {th }}$ of May, which is the official ${ }^{1}$ electoral campaign span. Legally, the cam-

1 https://mai.gov.ro/index03_2_04_6.html (07/2019). 
paign was over on the $25^{\text {th }}$ of May at 7:00 P.M., and both parties have complied with the deadline by not posting any self-promoting materials during the election day.

The Facebook posts have been analyzed from two perspectives. One focus point is thematically seeing any topic overlaps and how the main topics were approached by the two parties, while also determining from which perspective the issue was presented. Apart from the different political views declared by the parties, the area of interest for this research is the balance between Europe-related matters and other topics.

The second focus point is related to the public reactions towards the published content and how Social Media can have a participation function. As Facebook is regarded as a feedback carrier, an interesting finding was researching the communication both ways and seeing not only what the political party has shared with the electorate, but also how the people reacted and commented on the posts. The following article sections show the findings separately for each party, and next, a parallel of PSD and USR-PLUS analysis results is displayed.

\subsection{Social Democratic Party (PSD)}

During the 30 electoral campaign days, the Romanian political party PSD has published 41 Facebook posts and it has received from its public more than 10,000 positive feedback remarks as "like" and "love" reactions. Almost all the posts include visual or audio-visual content, as a support for the written paragraphs. There is only one post that only contains text and it represents $2 \%$ of the total posts count. Only $32 \%$ of the posts are pictures, whereas the remaining $66 \%$ is represented by video content.

The political actor who is most frequently presented is the PSD party leader at the time, Liviu Dragnea. There is only one group photo where the PSD candidates Plumb, Nica, Avram, Terhes are present without the party leader. Although none of the pictures are portraits of a single candidate or political actor, the presentation of the candidates and party leaders is handled in the videos. 16 of the total 27 video posts are showing Liviu Dragnea as the political leader, speaking at the meetings that the party organized as part of the campaign. Beside him, in 2 of the videos, stands the PSD candidate Rovana Plumb, who also spreads the electoral message to the crowds. Throughout the videos, more of the PSD members and partisans are shown and testify on the results of PSD.

There are 7 agenda setting topics addressed in the PSD Facebook Communication. The word Europe is mentioned 10 times in 41 posts and in 5 of them, the focus is on the double standards and on the fact that the European Union is mistreating Romania. The campaign slogan, present in $30 \%$ of the posts is Romania deserves 
more respect? ${ }^{2}$ and it is also very often stated throughout the communication channel Facebook.

The topics are the economic growth, as a result of PSD governance, with 27 posts, the European double standard that implies the fact that PSD has fought for Romanians to have the same wages and product quality for imported goods, with 3 posts, the future of the youth in Romania and building better perspectives, with 3 posts, the PSD candidates as patriots who fight for Romania's vote in the European decision-making process, with 2 posts, doctors coming back to work in Romania, as a result of salary increase and better working conditions, with one post, and the criticism regarding PNL and President Klaus Iohannis, with 2 posts. The majority of the electoral messages, namely $68 \%$, revolve around the economic growth that is, in $100 \%$ of the cases, explained as pension increase, salary increase, GDP and job occupation increase. In one of the videos, besides the increased investments, the intention to build highways is stated: This new building site is adding to the already open ones [...]. We are determined to [...] accelerate the most we can the construction of motorways ${ }^{3}$. The maximum comment count is 1,400 for a short video entitled We continue to fight for Romania! . In the video, the party leader at that time, Liviu Dragnea, is encouraging people to vote on the $26^{\text {th }}$ of May and says that PSD, together with the people, must continue to defend the economic growth of Romania, to build a European future for Romanians.

The comments to the 41 Posts can be divided into three major categories: sympathizing comments, in which the person praises the party and the candidates, the detractor comments that are criticizing the party and the non-related comments that are posted as random jokes or spam. There are 2 relevant comments selected by Facebook per post. These are the comments with the most reactions and responses. An interesting finding is that $68 \%$ of the total of 82 relevant comments are detractor comments, while only $32 \%$ are sympathizing comments and only one comment is non-related. The most commented posts are, for example: You have achieved remarkable performance, my dears. PSD hasn't yet built so many motorway kilometers as the kilometers covered by people who stand in line to vote ${ }^{5}$, PSD vote! All PSD programs have been and still are REALIST. For the wellbeing of the citizens:

2 Originally in Romanian: "România merită mai mult respect!

3 Originally in Romanian: "Acest nou șantier se adaugă celor deschise deja [...]. Suntem deciși să [...] accelerăm la maxim construcția autostrăzilor”, https://www.facebook.com/psdbiroupresa/vi $\operatorname{deos} / 2516846985234428 /$.

4 Originally in Romanian: „Continuăm lupta pentru România!”, https://www.facebook.com/psdbiroupresa/videos/305765743680627/.

5 Originally in Romanian: "Ați reușit o performanță remarcabilă dragilor. Nu a făcut PSD-ul kilometri de autostrăzi câți km de cozi au făcut oamenii să voteze”. 
children, employees, pensioners, etc. Congratulations! I vote the PSD list and do not participate to the useless referendum....'.

The copy strategy shows optimistic, confident thinking about the results of the PSD governance so far, with a great focus on internal topics: the wellbeing of the Romanian citizens, the increase of pensions and salaries and the future of the Romanian younger generations are the key topics. The copy with mobilization function is written as a statement and the analysis shows no attempt to interact with the public, as no post has open ended questions or a call to action for people to react in the comments. The only call to action present regards the voting.

The wording for the political discourse is simple, denotative and built on repeating core statements with the help of short sentences and a tendency to generalize: "Now more than ever is the time to be united", "We have to protect our future and the future of our children!, PSD is the party that increased pensions, salaries, income for medical staff and teachers." In the audiovisual materials, there are three types of personas present: the political actor in front of a cheering crowd, the hard-working farmer, happy young people in front of a computer screen. Keywords for the PSD message are: economic growth, together, better future, double standard, patriots.

\subsection{Union Rescue Romania - PLUS (USR-PLUS)}

The USR-PLUS Coalition has posted 200 times on Facebook during the electoral timespan. The reactions of the public included more than 150,000 positive feedback showings that were transmitted as Like and Love reactions. $100 \%$ of the published posts are supported by visual or audio-visual content like pictures, videos, links. 142 of the posts include pictures, 9 of them include links and the remaining 49 are shared videos.

In the USR-PLUS posts, most of the posts are about Dacian Cioloș, in 36 posts. Other party candidates, like Dragoș Pîslaru, with 12 entries, the USR Plus president, Dan Barna, with 7 entries, are featured in the posts, mostly as counterparts to the current reigning political actors. There are 9 comparison posts between the USR Plus and PSD party members, in which the PSD initiatives are criticized and the studies and results of the USR Plus political actors are recommending them. Examples are: Oana Florea (PSD) and Naomi Reniuț-Ursoiu (USR Plus), Natalia Intotero (PSD) and Oana Țoiu (USR Plus), Maria Grapini (PSD) and Clotide Armand (USR Plus).

6 Originally in Romanian: "VOT PSD! Toate Programele PSD au fost și sunt REALISTE ! Pentru binele cetățenilor: fie copii, fie salariați, fie pensionari etc. Felicitări ! Votez lista PSD și nu particip la referendumul inutil...!”.

7 Originally in Romanian: “Acum mai mult ca oricând este momentul să fim uniți, Suntem datori să apărăm viitorul nostru și al copiilor noștri!, PSD este partidul care crește pensiile, salariile, veniturile medicilor și ale dascălilor.” 
There are 16 broad topics addressed in the USR PLUS Facebook Communication. In their posts, the word Europe appears 93 times and is presented as part of Romania's future. Working in the European Union is a way for the younger generation to live better: For Tudor, Europe is open today. For him, there is a world full of opportunities out there. This is the difference that this small document [the passport] makes for the nowadays generations. ${ }^{8}$

The topics are competences of the USR PLUS candidates and their studies, with 67 posts, Romanian international and national rights, with 22 posts, education, including schools and universities, with 22 posts, addressing the motorway problems and searching for the guilty part, with 12 posts, EU funds and EU funding prospects, with 12 posts, health care system, including funds, doctors and technology, with 11 posts, infrastructure, with 10 posts, diaspora and Romanians everywhere and their rights to vote, with 8 posts, economy in all sectors, with 8 posts, children together with younger generation and their future, with 7 posts, investments and investment plans, with 6 posts and agriculture, with 6 posts. Three posts were dedicated to each of the following topics: Schengen, Erasmus mobility programs, security.

There is more than one Facebook campaign slogan present as three core phrases are to be discovered: Without thievery we will make progress! with 25 posts, Vote on the $26^{\text {th }}$ of May! with 28 posts, Together we ... win/head towards victory/write history! with 33 posts. One particular fact about the political discourse is the proven presence of often heavy critique on PSD, whereby the political party's name, PSD, is mentioned 46 times and the name of the PSD leader, Liviu Dragnea, is mentioned 18 times.

The most commented post has also received 1,400 messages from the readers. The elements of the post are: a short question with a call to action: Will you be voting at the referendum? Answer in the comments. The visual support is a picture with the same written text.

The three categories described above are also identified for the political party USR PLUS` Facebook page. These are the sympathizing comments, the detractor and the non-related comments. The 2 relevant comments selected by Facebook show that $74 \%$ of the 400 comments imply positive words and phrases like we support USR Plus, together we will improve the living situation in Romania. As about $2 \%$ of the comments are unrelated to the party or campaign, $24 \%$ of the public's reactions are marked by disappointment, critique or insecurity: stop criticizing and show us results, all politicians are thieves, you included, you are too small to count. Some more vivid examples are: I'd like to see a different campaign. I think that

8 Originally in Romanian: "Pentru Tudor, Europa este astăzi deschisă. Pentru el, există o lume de oportunități. Aceasta este diferența pe care acest scurt înscris o face pentru generațiile actuale.” 
people would be better served if you told them how your presence in the EU Parliament will improve their life and not how you will humiliate PSD...', It is my first vote full of enthusiasm and hope in the last 23 years. It's now or maybe never ever again. I vote Alliance 2020 USR PLUS !! ${ }^{10}$ A characteristic of the communication is the big English words used, like now or never, love, future.

The tone of the voice is friendly, approachable, with a note of expertise. The balance between internal and external topics is ensured by a variety of 15 topics. The argumentation is strongly provided by numbers and facts, which are present not only for promoting the candidates, but also in case of criticism. The main ideas in the political speech are the need for change in Romanian politics, a fresh perspective and preventing the politicians with criminal record from running for the post: No person with criminal record as a civil servant. The visual materials include portrait pictures of the USR Plus Candidates, the political actor in the middle of the people, dynamic postures and young people. Keywords for the USR Plus message are: together, change, theft, corruption, improvement.

\section{The newspapers of the two parties}

The analysis of the two newspapers plans to go in three directions. On the one hand, the thematic fields are identified and named, then the reflections on the main topic 'Europe' are examined and finally the pictures from the newspapers are quantified and their nature explained. Consequently, the study is both qualitative and quantitative. It is also important to clarify the differences between the two newspapers from the perspective of their agenda.

\subsection{PSD newspaper: Romania deserves a better place in Europe}

The newspaper, which contains the party's election slogan as its headline, consists of eight pages. The chosen slogan, Romania deserves a better place in Europe ${ }^{11}$, summarizes actually the main idea of the PSD election campaign. The party describes itself as the most efficient party in the area of the European fund absorption $^{12}$ and the result is a new slogan, namely that Romania deserves more European funds! $!^{13}$

9 Originally in Romanian: "Mi-ar plăcea să văd că faceți campanie 'altfel'! Cred că oamenii ar fi slujiți mai bine dacă le spuneți cum prezența voastră în Parlamentul European le va îmbunătăți viața, nu cum veți 'mătura pe jos' cu PSD...”.

10 Originally in Romanian: "Este primul meu vot plin de entuziasm şi speranță din ultimii 23 ani. It's now, or maybe never ever again. Eu votez Alianța 2020 USR PLUS !!”.

11 Originally in Romanian: "Romania merita mai mult in Europa!".

12 Originally in Romanian: "PSD, cel mai eficient partid în domeniul absorbției fondurilor europene". 13 Originally in Romanian: "Romania merita mai multe fonduri europene!”. 
The whole newspaper contains Europe-related topics and the articles are visually accompanied and supplemented by highly suggestive and well-made charts, graphics and photos. The red color dominates when the party's success is presented and in the background of the slogans we can notice the Romanian and the European Union flags. On each page, at least an achievement of the party is listed and described.

The first five pages of the newspaper list the successes of the government and the promises for the future. We learn that the Romanian farmers have received European funds ${ }^{14}$ and for the future, as a goal, PSD promises healthy food from Europe for the children in Romania ${ }^{15}$, quality medicines for children in Romania ${ }^{16}$ and no counterfeit drugs, state of the art equipment in hospitals ${ }^{17}$ and last but not least the quality of food should be in Romania as everywhere in Europe ${ }^{18}$.

Another much discussed issue is the difference between Romanians and other European citizens. PSD believes that during this governance, such differences have diminished a lot. PSD bridges the gap between Romanian and European citizens ${ }^{19}$ and in this context, there are comments made regarding the following areas, also featured as achievements of the political party: the average wage increase, the increasing of the public employees' salaries, the pension increase and several reduced fees for pensioners. It is also mentioned that the unemployment rate has dropped and the purchasing power of employees and pensioners has increased. The conclusion of the political party is that Romanians, as a result of such measures, came out of poverty and that the national economy goes well during the PSD governance ${ }^{20}$.

On page five, the reader can find a message from Liviu Dragnea. In March 2019, when the newspaper was released, he was still the president of the political party. Dragnea, as a representative figure for PSD, formulates a message summarizing the greatest achievements of his party. His exclamations at the end serve as appeals to readers: Romania deserves more! We must accomplish the government program? ${ }^{1}$

Page six offers the reader an image regarding the political attitudes and actions of the government and the opposition. The focus is on Prime Minister Viorica Dăncilă and she is described as the protector of Romania in the European Parlia-

14 Originally in Romanian: "Fermierii romani au încasat fonduri europene".

15 Originally in Romanian: "Alimente sănătoase din Europa pentru copiii din Romania”.

16 Originally in Romanian: "Medicamente de calitate pentru copiii din România".

17 Originally in Romanian: "Echipamente performante in spitale".

18 Originally in Romanian: "Aceeași calitate a alimentelor ca peste tot in Europa".

19 Originally in Romanian: "PSD reduce diferențele dintre cetățenii romani și cei europeni”.

20 Originally in Romanian: "Economia naţională merge bine în timpul guvernării PSD".

21 Originally in Romanian: "România merită mai mult! Trebuie să ducem programul de guvernare până la capăt!". 
ment. Keeping the same laudatory tone, the reader is informed on how well - prepared and responsible Minister Rovana Plumb is. In a column on the edge of the page we can see a "List of Shame"22, which contains nine Euro-MPs from PNL and USR, who have voted, according to the newspaper, a resolution against Romania. The self-staging and the representation of others is certainly not surprising for anybody. The demarcation from the others reaches the climax with the so-called "List of Shame".

This clear distinction from the political opponents continues on the next page and now the focus is on President Iohannis. The national economy is going well, but it would have worked even better, if President Iohannis hadn't always put a spoke in the wheel ${ }^{23}$.

The last page brings a message with an appeal function: Dare to believe in Romania! Our country has been and can be among the first states in Europe $e^{24}$. We can also notice a string of arguments for this call: assertions written in red to stand out immediately, schematic enumerations and some images that summarize the written part. On this page of the newspaper, a new column appears, bearing the title "Did you know... ${ }^{25}$ in which six decisions are listed, which have been taken or are going to be taken by the opposition parties and which are, according to the newspaper, against the welfare of the Romanian citizens.

The newspaper ends with a survey containing four questions. The first question is an open one and asks the respondents about the main problem to be solved in Romania ${ }^{26}$. The following three have multiple choice answers and request the reader's agreement or disagreement in connection with several actions of PNL and USR-PLUS. The second question is extremely interesting and hard to comment on. It tries to determine to what extent the respondent agrees with the USR-PLUS proposal to surcharge the beans for reducing farts that would pollute the air too much!?!"27.

The visual part of the newspaper consists of seven pictures and a considerable number of graphs and charts. According to Gerster $(2002,105)$ "without pictures, there is virtually no message, no real campaign. Images stick in the memory. Deleting them is hard". The four pictures of children are well chosen and contribute to the major emotional impact of the topic and subsequently the text on the viewer.

\footnotetext{
22 Originally in Romanian: "Lista rușinii".

23 Originally in Romanian: "[...] daca președintele Iohannis nu ar fi băgat mereu bețe-n roate”.

24 Originally in Romanian: "Îndrăznește să crezi in România! Țara noastră a fost și poate fi printre primele state din Europa".

25 Originally in Romanian: "Știați că...”.

26 Originally in Romanian: “Care este principala problemă care trebuie rezolvată urgent în România?”.

27 Originally in Romanian: "În ce măsură sunteți de acord cu propunerea USR-PLUS cu o suprataxă la fasole pentru reducerea pârțurilor care ar polua prea mult aerul?”.
} 
With this strategy, the newspaper steps heavily on the emotional pedal and wants to stir up different positive feelings, which can be associated by default with the political party. The charts and graphs are purely informative, but by summing up the written message in a single image, they become conclusive and can easily be decoded by the reader.

The topics approached are quite general and the approach is straightforward. Any counter-argument is missing completely. The main strategy is the delimitation from the other political actors. The self-staging is impeccable, immaculate and the image of the others is without exception very negative. Everything is in white and black tones; PSD has only done good, PNL and USR-PLUS only made decisions against the Romanian citizens and follow their setback.

\subsection{USR-PLUS newspaper: Without thievery we get far}

Just like the other newspaper, the USR-PLUS newspaper also consists of eight pages and has, as its headline, the most famous electoral slogan of the new coalition: Without thievery we get far ${ }^{28}$. The term thievery appears often in the lines of the newspaper and becomes a key-word.

The newspaper also contains, besides other promotional texts of the USR-PLUS alliance, an editorial about Dacian Cioloș, president of PLUS and an interview with Dan Barna, president of the USR. Both consider these elections to be the most important elections for the European Parliament ${ }^{29}$. The Europe-related topic can be found in the USR-PLUS plan for Romania in Europe $e^{30}$ : the coalition wants the Romanians to fully benefit from the safety, wealth and prosperity of Europe.

We've joined together and we're heading towards victory ${ }^{31}$. This is another important slogan of the alliance and refers both to the USR-PLUS union, as well as to the historical past of Romania and to the centenary of the Great Unification. The newspaper attempts to make a parallel between the leaders of the State 100 years ago by listing their names and those who are now at the Romania's forefront. Building on this idea, the reader learns that USR and PLUS have made an electoral alliance to give the decent people of Romania an alternative that can win an election ${ }^{32}$. These references to the historical past and to the prominent personalities of that time show the new coalition's opinion to its readers and potential voters: it is about an informed, knowledgeable and educated audience.

28 Originally in Romanian: "Fără hoție ajungem departe".

29 Originally in Romanian: "Cele mai importante alegeri europarlamentare".

30 Originally in Romanian: "Planul USP PLUS pentru România în Europa”.

31 Originally in Romanian: "Ne-am unit și mergem la victorie".

32 Originally in Romanian: "[...] pentru a oferi oamenilor decenți din România o alternativă care poate să câștige alegeri”. 
As we have already specified, the word thievery is repeated very often and the alliance USR-PLUS proposes a Manifesto without thievery ${ }^{33}$, in which they list why we should go to vote: without thievery, we have hospitals, we finish the motorway's construction, we repair schools, we get far. These topics are actually more of national interest and less related to Europe. This manifesto seems more like a verbal battle with those in the PSD party and a tough criticism against them, as they are seen as the main cause for Romania's incapacity to take a step forward. The PSD image is associated with a thievery octopus ${ }^{34}$, and the party is described as a corrupt one, where nepotism is encouraged. The climax of criticism is reached by the assertion that the PSD struggles, employing all its energy, to stop the appointment of Laura Codruta Kövesi as European general attorney because they know thievery will be harder for them ${ }^{35}$. All comes again to that word.

The editorial on page four features Dacian Cioloș as a simple, responsible man and in order to highlight these qualities, the most important achievements during his governance are presented. All the performances in the field of health care, labor and education are listed and explained very extensively. The most important seems to be the anti-poverty measures.

On the next page appears an interview with Dan Barna. He sees investing in young people as the main chance for Romania and explains how they should be persuaded not to leave the country. In addition, the law for the special pension elimination and the initiative called without corruption in public functions ${ }^{36}$, both submitted to the Romanian Parliament, are remembered and explained in detail.

The next two pages bring to the forefront the best candidate list, according to the newspaper. Twelve candidates are briefly described and presented in very wellchosen images: the hypostases in which they appear are highly suggestive, the candidates are in action and interaction, are smiling and they emanate confidence.

The manner in which the newspaper is written is serious: important topics are addressed and the statements made are explained and argued. Although the image of the other is eminently negative, and heavy words and critical talk are thrown, the reader also gets the justification for the statements issued. The USR-PLUS coalition describes itself as an alternative that can win the elections. For the image of the others, terms such as, thievery octopus and corruption are used. According to the coalition, the main occupation of PSD is stealing.

\footnotetext{
33 Originally in Romanian: "Manifest fără hoție".

34 Originally in Romanian: "Caracatița de hoție".

35 Originally in Romanian: "PSD se luptă cu toată energia să oprească numirea Laurei Codruța

Kövesi în funcția de procuror general European pentru că știu, că le va fi și mai greu să fure”.

36 Originally in Romanian: "Fără penali în funcții publice".
} 
The topics discussed in the texts are mainly of national interest and less related to the European elections. Only in conclusions, where some references to the coalition's goals are enumerated, the reader can find topics such as the European funds, the rights of Romanians living in Europe, the joining of the Schengen area or the extending of the Erasmus mobility program for pupils. The future of Romania as part of the European Union is also being discussed here and the USR-PLUS coalition wishes that all pro-European forces unite.

\section{Discussions and conclusion}

Comparing the quantitative data about the two political entities URS-PLUS and PSD, some clear differences can be noticed. Firstly, the frequency and the count of the posts show that PSD only published 41 posts whereas USR-PLUS communicated 200 messages to their audience. This gap of 1 to 4,87 post check off influenced the complexity of the topic range as the 7 topics approached by PSD are much fewer than the 16 themes of USR-PLUS`s interest (see Table 1). One consequence would be the difference of 140,000 Like and Love Reactions the posts have gathered, whereas an interesting finding is that the number of comments is of 1,400 for the most commented post for each party.

Table 1. The Facebook analysis article diagrams

\begin{tabular}{lll}
\hline PSD & USR Plus & Comparison \\
\hline 41 Posts & 200 Posts & $1 / 4.87$ \\
\hline 7 Topics & 16 Topics & $1 / 2.28$ \\
10,000 Likes, Love Reactions & 150,000 Likes, Love Reactions & 140,000 \\
$66 \%$ Videos, & $71 \%$ Pictures, & \\
$32 \%$ Pictures, & $24.5 \%$ Videos, & almost $100 \%$ audiovisual content \\
$2 \%$ Texts & $4.5 \%$ Links & Balanced reaction numbers \\
\hline 1,400 Comments & 1,400 Comments & \\
\hline
\end{tabular}

Furthermore, almost all posts consist of audio-visual content. Out of the 241 analyzed posts, only 1 post from PSD is text-only.

Topic related overlaps are to be considered for three broad issues: the future of the younger generations, the situation of the health care system and the medical doctors and the lack of motorway issue. Both parties showcased their most popular political actor: Liviu Dragnea appears in 39\% of the content, whereas the name of Dacian Cioloș is featured in 18\% of the Facebook content (see Figure 1). A similarity between the two communicators is that they both use visual and audio-visual support for their content, adjusting the content to the Facebook environment's requirements. The topic most addressed by USR-PLUS is the competence of the candidates with 67 posts, whereas the topic most addressed by PSD is the economical raise with 26 posts. 
The central issues regarding Europe and the European Parliament elections has been very differently presented by the two parties. For one thing, USR-PLUS promotes Romania as part of the European Union, which helped the country develop and has opened new paths for Romanians. On the contrary, PSD is discussing the double standards for the European countries and blames the European Union for not caring about the life quality in Romania.

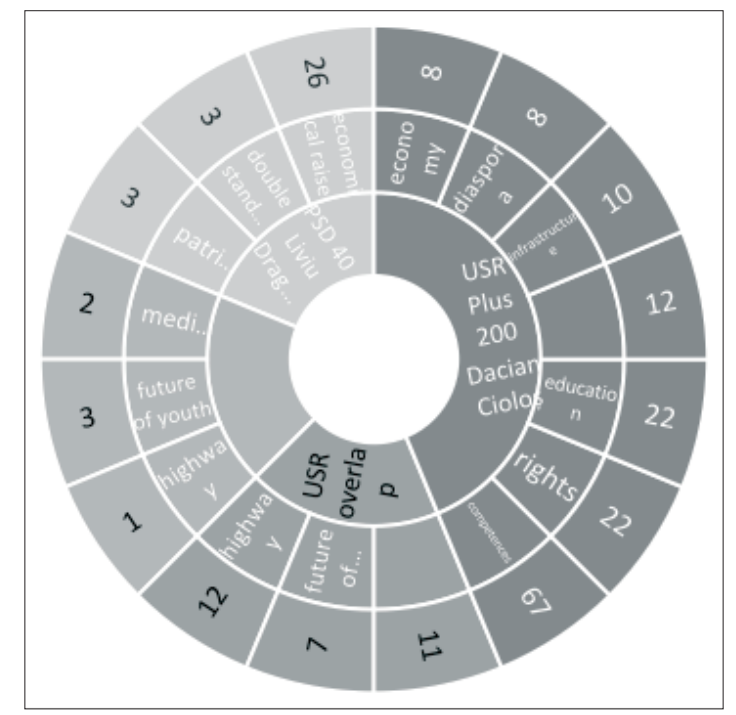

Figure 1. Thematic overlap

As for the campaign slogan, PSD had a clearer vision on how to promote their tagline, as USR PLUS branded more types of content, such as events, posts or statements with more than one clear tagline. On the other hand, only the comments for the USR-PLUS have shown people actively sharing the campaign taglines as the campaign hashtags "\#undoi and \#doideda" were constantly used in comments. Another difference is the amount of positive and negative feedback: USR-PLUS has a total percent of $74 \%$ positive most relevant comments, while PSD has more negative feedback with only $32 \%$ supporting comments (see Figure 2).

The copy strategy emphasizes some distinctive traits of the political speech. As PSD uses a more official, sober tone with easy denotative wording and a lack of wordplay, the USR-PLUS strategy is different and offers more dynamism as the tone is friendlier and more approachable with a hint of experience and knowledge. The way the two political parties build their agenda is suited to their roles in the elections: PSD is a party with history in Romania and USR has the role of the challenger (see Table 2). 


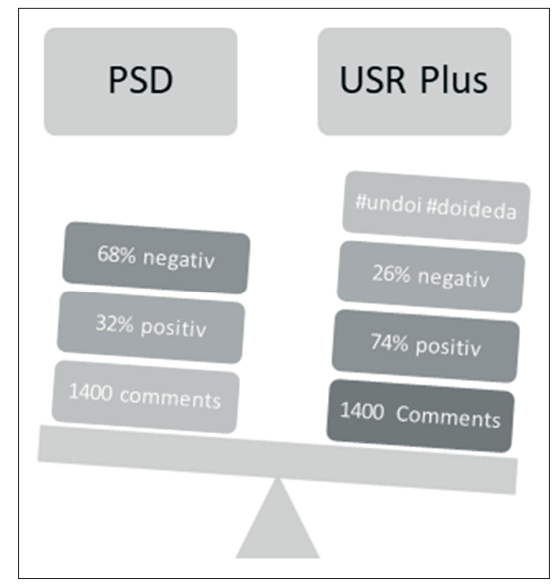

Figure 2. Feedback and comments

Table 2. Focal points in campaign communication

\begin{tabular}{|c|c|c|}
\hline Comparison & USR Plus & PSD \\
\hline Tone of Voice & $\begin{array}{l}\text { friendly, open, experienced, } \\
\text { argumentative, criticizing, CTA }\end{array}$ & $\begin{array}{l}\text { optimistic, simple, formal, } \\
\text { no CTA, general, denotative }\end{array}$ \\
\hline $\begin{array}{l}\text { Focal Point in } \\
\text { Campaign Communication }\end{array}$ & $\begin{array}{l}\text { USR Plus as a catalyst for change } \\
\text { in Romanian politics }\end{array}$ & $\begin{array}{l}\text { The PSD patriots have increased } \\
\text { salaries and pensions. }\end{array}$ \\
\hline Promoted Concepts & $\begin{array}{l}\text { The competencies of the candidates, } \\
\text { facts, strong criticism of PSD, EU topics }\end{array}$ & $\begin{array}{l}\text { Results, internal topics, } \\
\text { Double standard }\end{array}$ \\
\hline Slogan or Tagline & $\begin{array}{c}\text { "No persons with a criminal record } \\
\text { in public functions." }\end{array}$ & "Romania deserves more respect" \\
\hline Party Identity & Confusing, many logos, many slogans & clear, uniform, one slogan \\
\hline Audiovisual elements & Portraits, dynamic attitude, young people & $\begin{array}{l}1 \text { candidate photo, } \\
16 \text { videos of Dragnea }\end{array}$ \\
\hline Keywords & $\begin{array}{l}\text { Change, Together, Theft, } \\
\text { Corruption, Development }\end{array}$ & $\begin{array}{c}\text { More Money, Together, Better Future, } \\
\text { Double Standards, Patriots }\end{array}$ \\
\hline
\end{tabular}

PSD's strategy was to point out their results and victories as a governing party, so they could be seen as the reliable party for the elections. USR-PLUS chose to openly criticize the PSD initiatives and to position themselves as a younger, more competent and more trustworthy option. The human touch on the copy was more present in the USR-PLUS Case, which featured the party's candidates in 67 posts that included the success story of the party members. PSD didn't focus on presenting the candidates and placed only the party leader in the spotlight.

USR-PLUS generally addressed more topics and supported the claims with data and facts while seeming interested in being part of the EU decision making process that was presented as being similar to the Romanian one. PSD broadly covered domestic matters and didn't seem to let the European Union be the center of their 
campaign strategy. The PSD candidates were staged as patriots, who will solely represent Romania's interest as members of the European Parliament.

Among the resulting keywords of each party, there was one match, which was marked by both, including the concept of improvement, leading to a better future, which was found in their discourse. Although the approach is not completely similar because PSD is implying that their internal political initiatives are already shaping a better future for the younger generation, while USR-PLUS argues that the high number of emigrants, price increase, poor life quality are the results of corruption and thievery happening in Romania.

The conclusive results show a different approach used for their Facebook Channel by the political parties, USR-PLUS and PSD regarding the on-line communication for the European Parliament Elections. The similarities between the two strategies are minor and consist of three topic overlaps and the use of audio-video support content for the published texts. The differences are distinguishable by observing the huge gap between the number of posts, which in the case of USR-PLUS was much higher. Not only did it bring a wider variety of topics for the communication, but it also showed that PSD did not invest as much effort in their on-line Facebook Communication for this campaign.

The major difference between the two newspapers lies in the attitude towards the reader and the vision towards Europe. While in the newspaper distributed by the PSD, there is a continuous criticism against the opposition parties, without bringing arguments and without explaining to the reader such assertions, in the USR-PLUS newspaper, we notice the reasons and causes of criticism. By knowing the arguments and the facts, the reader can get an idea of the situation and can form an opinion. Differences are also noticed in the field of language use. The PSD newspaper uses a simpler, denotative vocabulary, compared to the other newspaper, which uses a more well-kept, connotative language.

The image of the two parties' main political actors is also drawn up differently. While Viorica Dăncilă and Rovana Plumb are described as protectors of Romania, especially in front of the European institutions, Dan Barna and Dacian Cioloș are portrayed as simple and responsible leaders. The focus falls on their political achievements and initiatives. Such facts should speak for them, not an endless praise from the newspaper.

There are also some differences in the visual part of the two newspapers. In the USP-PLUS newspaper we notice the presence of a much larger number of images: on the one hand, there are pictures of the candidates from the electoral roles (12 pictures) and the leaders of the coalition are featured in different situations (in front of the media representatives, during the campaign or talking to the voters, 4 pictures), and on the other hand, there are pictures meant to summarize and 
highlight a verbal message (6 pictures). The ten pictograms on the last page of the newspaper visually summarize the plans of the Alliance 2020, goals for which they will fight in the European Parliament.

The first part of the hypothesis is confirmed: the newly formed USR-PLUS coalition discusses a wider range of topics in its publication. However, most of them are national interest issues and only part of them relate to Europe and the European elections.

The thematic binder of the two newspapers is undoubtedly Europe. The reader sees a different vision of what Europe and the European Union mean for the two political parties. If the USR-PLUS coalition associates the European space with values such as welfare, prosperity, normality, stability and safety and wants Romanians to benefit and take advantage of them, the PSD newspaper displays a constant suspicion that Europe does not treat us correctly (the idea of the double standard), that we are not seen as equal to the other Europeans, and that we must always keep an eye on the European leaders, so that they do not make any decision against our country.

The originality of the contribution stems in particular from the choice of the two parties that were examined. As already mentioned, the analysis concentrates on a political party with a long tradition and a high profile, the PSD, and a new coalition USR-PLUS consisting of young and little-known political actors. The fact that they are so new in the political party system may lead them to bring new issues and ideas to the public. This is exactly the hypothesis of our study, namely whether there are differences in the issues addressed by the two parties, or whether they are dealing with the same topics.

The limits of the study lie in the number of political formations explored. In order to increase the scientific relevance of the contribution, it would be necessary to extend the analysis to other important and established political parties and coalitions that play an important role in the Romanian political system. Such an extension would provide an overall picture of the Romanian current political landscape.

\section{References}

1. Denton, Robert Jr.; Trent, S., Judith; Friedenberg, V., Robert (eds.) (2019). Political Campaign Communication: Principles \& Practices. $9^{\text {th }}$ edition, London: Rowman \& Littlefield Publishing.

2. Emmer, Martin (2019). Online-Kommunikation politischer Akteure. In Schweiger, Wolfgang; Beck, Klaus (eds.), Handbuch Online-Kommunikation, 2end edition (pp. 369392). Wiesbaden: Springer.

3. Gibson, Rachel; Ward, Stephen (2000). A Proposed Methodology of Studying the Function and Effectiveness of Party and Candidate Web Sites. Social Science Computer Review, 18(3), 301-319. 
4. Hinz, Kay (2016): Kandidaten und ihre Unterstützer im Online-Wahlkampf. Die Bundestagswahlen $2013 \mathrm{im}$ Web 2.0. Wiesbaden: Springer.

5. Hinz, Kay (2017): Aktivitäten auf Facebook und Twitter zur Bundestagswahl 2013: Onlinekommunikation von Kandidaten im Wahlkampf. Media Perspektiven, 3, 170-178.

6. Maurer, Markus (2016). Journalismus und Agenda-Setting. In Löffelholz, Martin; Rothenberger, Liane (eds.), Handbuch fournalismustheorien (pp. 20-45). Wiesbaden: Springer.

7. McCombs, Maxwell, E.; Shaw, Donald, L. (eds.) (1972). The agenda setting function of mass media. Public Opinion Quarterly, 36(2), 176-184.

8. McCombs, Maxwell, E. (2004). Setting the agenda. The mass media and public opinion. Cambridge.

9. McCombs, Maxwell, E.; Reynolds, Amy (2009). How the news shapes our civic agenda. In Jennings, Bryant; Mary Beth Oliver (eds.), Media effects. Advances in theory and research (pp. 1-16). New York/London.

10. Melischek, Gabriele; Rußmann, Uta; Seethaler, Josef (2010). Agenda Building in österreichischen Nationalratswahlkämpfen: 1970-2008. In Plasser, Fritz (ed.), Politik in der Medienarena. Praxis politischer Kommunikation in Österreich, (pp.101-144). Wien: Facultas.

11. Norris, Pippa (2000). A Virtuous Circle. Political Communication in Postindustrial Societies. Cambridge University Press.

12. Reese, Stephan, D. (1991). Setting the media's agenda. In Anderson, James, A. (ed.), Communication Yearbook, vol. 14 (pp. 309-340). Newbury Park/London/New Delhi,.

13. Rottbeck, Britta (2013). Der Online-Wahlkampf der Volksparteien 2009: Eine empirische Analyse. Wiesbaden: Springer.

14. Rössler, Patrick (1997). Agenda Setting. Theoretische Annahmen und empirische Evidenzen einer Medienwirkungshypothese, Wiesbaden: Springer Fachmedien.

15. Rössler, Patrick (2006). Zur Logik der Agenda Setting Forschung. In Wirth, Werner; Fahr, Andreas; Lauf, Edmund (eds.), Forschungslogik und - design in der Kommunikationswissenschaft. Anwendungsfelder in der Kommunikationswissenschaft, vol. 2 (pp. 139167). Köln: Herbert von Halem.

16. Panagopoulos, Costas (2009). Technology and the Modern Political Campaign. In Panagopoulos, Costas; Gueorguieva, Vasia; Slotnick, Allison (eds.), Politicking online: The Transformation of Election Campaign Communications (pp. 1-18). London: Rutgers University Press.

17. Voss, Kathrin (ed.) (2014). Internet und Partizipation. Botom-up oder Top-down? Politische Beteiligungsmöglichkeiten im Internet, Wiesbaden: Springer. 